\title{
World Views and the Evaluation of NGO Supply Chains: Thirteen Cases from Guatemala
}

\author{
Stephen A. LeMay \\ University of West Florida, USA \\ Email: slemay@uwf.edu \\ Michael J. Dwyer \\ Colonia Villa Sol, Guatemala \\ Email: Dwyer.michaelj@gmail.com \\ Marilyn M. Helms \\ School of Business, Dalton State College, USA \\ Email: mhelms@daltonstate.edu (Corresponding author)
}

\begin{abstract}
The city of Antigua, Guatemala is a frequent destination for volunteer tourism and home to numerous non-governmental organizations (NGOs), including many international charities and humanitarian aid organizations. The area is ideal for studying disaster relief and humanitarian supply chains as well as the problems these supply chains face operating at the center of clashes between world views and cultures. In this research, we assess the impact of these world views on NGO supply chain practices, evaluate NGOs understanding of supply chain theory and practices and present 13 cases of potential, growing, and successful NGO relief examples. From the field research, we developed a classification framework and identified nine specific criteria that NGOs must meet to sustain success. We discuss the implications of the framework for future research.
\end{abstract}

Keywords: disaster relief, Guatemala, NGOs, supply chain management.

\section{INTRODUCTION}

The city of Antigua, Guatemala is surrounded by four jungle covered volcanoes and the city center is dotted with churches that have stood for centuries. The cobblestone streets are crowded with pedestrians, motorcycles, cars, and tuktuks, covered three wheeled vehicles often used as taxis. The population ranges from tall, pale Europeans who work for international NGOs to Mayans who are a foot shorter and much darker. The city seems the ideal setting for epics like the "The Lord of the Rings." It seems the city should be rife with elves, ghosts, and mysterious rings.

Instead it is populated by tourists, NGO volunteers, Mestizos, Criollos, Ladinos -- all terms for European or mixed-European descent residents -- and Amerindians, indigenous people that include the K'iche, Kaqchikel, Mam, Q'eqchi, and other Mayans. European and North Americans make up nearly $40 \%$ of the population in Antigua. This is largely because Antigua is a tourist destination, and because it is home to many non-governmental (nonprofit, service) organizations, including many international charities and humanitarian aid organizations (Fenton, et al., 2011; Kiser, et al., 2009; Berry, 2014).

This makes Antigua an ideal place to study disaster relief and humanitarian supply chains, as well as the problems these supply chains face operating at the center of clashes between world views and cultures. Antigua specifically, and Guatemala more generally, have hosted both sudden and slow developing disasters and have dealt with them with varying degrees of success.

In this research, we assess the impact of world views on the NGO supply chain practices, evaluate NGOs understanding of supply chain theory and practices and present 13 cases of potential, growing, and successful NGO relief examples. The authors developed the To-For-With framework and identified nine criteria for classifying NGOs within that framework. Both the framework and the criteria emerged from the ethnographic, historiographic, qualitative research process. The sample of NGO cases are then classified within the To-For-With Framework as either a "To," a "For," or a "With" organization based on how many of the nine classification criteria the NGO exhibits. Discussion and further research based on the framework is presented. We begin with the methodology and continue the research by examining world views and their impact on NGO practices and patterns of thought.

Even though much has been written about supply chains (Krajewski, et al., 2012: Singhal \& Singhal, 2012; Hassini, et al., 2012), disaster relief efforts (Takeda, et al., 2008; Helms, et al., 2007; Takeda \& Helms, 2006 a \& b) and even humanitarian and disaster relief supply chains (Aurelie, et al., 2010), they are rarely considered as social constructs or the 
primary contact between clients and organizations, or as the primary touch points between customers and businesses. This research adopts the social construct viewpoint and positioning in its analysis.

\section{LITERATURE REVIEW: HUMANITARIAN AND DISASTER RELIEF SUPPLY CHAIN THEORY AND FRAMEWORKS}

Theory on humanitarian and disaster relief supply chains (HSC) suffers from several maladies. First, HSC relies on theories and definitions developed in the context of IT enabled supply chains that exist primarily in the developed world. These definitions tend to be top-down and to be flawed as definitions. For example, Blecken (2010) defined humanitarian logistics as the process of planning, implementing, and controlling the cost effective flow and storage of goods, materials, and equipment as well as related information, from point of origin to point of consumption for the purpose of meeting end users' requirements. This definition differs little from the 1991 definition of logistics (offered by what was then the Council of Logistics Management, and is now the Council of Supply Chain Management Professionals) as "part of the supply chain process that plans, implements, and controls the efficient, effective forward and reverse flow and storage of goods, services, and related information between the point of origin and the point of consumption in order to meet customers' requirements." These two definitions suffer from serious flaws. They add qualitative elements to the definition of the 'thing itself' - in these terms, logistics cannot be 'cost ineffective' in the first case, or 'inefficient' and 'ineffective' in the second. Both assume a purpose that in some fashion meets customer or client requirements, but not all logistics is well done, and not all logistics serves customers' need. And the same holds true for the now dominant term, 'supply chain management' (LeMay, Holt \& Schmurr, 2011; Mentzer, DeWitt, Keebler, Min, Nix, Smith, \& Zacharia 2001; Gibson, Mentzer, \& Cook, 2005; Lambert \& Cooper, 2000). Day, Melnyk, Larson, Davis, and Whybark (2012) point out that much of the HSC research has used the term 'logistics' rather than 'supply chain management.' In 2012, they identified 147 refereed articles on humanitarian logistics, but only 47 on humanitarian supply chains (Day, et al., 2012).

Second, the focus of frameworks and theories tends to be on sudden disasters-hurricanes and tsunamis, earthquakes and mud slides, forest fires and floods. These are problems that can certainly affect poor countries, but also affect the developing and developed world (Merminod, Nollet, \& Pache, 2014). Slow developing disasters are third world problems like extensive, unrelieved droughts, malnutrition, and poverty. They often fit poorly into existing HSC frameworks. Day et al. (2012) identified three major areas for HSC research and four areas for theory development and practical application. The three areas for HSC research were (1) convergence/ supply chain capital; (2) risk management; and, (3) emergent organizations. The four areas for theory development and practical application were: 1) demand signal visibility and requirements determination; 2) information management and relief activity coordination; 3) disaster relief planning; 4) and managing relationships and developing trust. In this research, we address many of these ideas, but we do so from a bottomup perspective.

Third, developed world, commercial supply chains are IT enabled. They tend to operate in a data rich environment, an environment that has little in common with humanitarian supply chains in Guatemala. Like commercial supply chains, humanitarian supply chains use procurement, transportation, warehousing, and inventory management; they may trace and track shipments or engage in bidding process, and reporting. But commercial supply chains employ experts in these areas and others (Gustavsson, 2003), where humanitarian supply chains are often using volunteers or Jack- and Jills- of all trades, people with far less expertise in these areas. Day et al. (2012) made the point in their discussion of supply chain capital and convergence: sometimes HSCs use the people who are there and integrate them into emergency supply chains, not because they are the most capable, but because they are the most available. Also, they point out that the mechanisms for capturing the results of a practice are often unavailable or ignored, so many HSCs end up inventing specialized knowledge that was already developed elsewhere, but not captured or communicated. Consequently, specialized knowledge is often lacking. They call for the development of mechanisms to capture and transfer this kind of information both between and within organizations (Day et al., 2012).

\section{NGOS, WORLD VIEW, SUPPLY CHAINS, AND CULTURAL CLASHES}

Academic disciplines are arguably socially constructed truths (Astley, 1985). Therefore it is no surprise business graduates differ from international relations graduates in their world view. Neither should it come as a surprise they carry these differing world views with them into the organizations that employ them as well as deploy them in locations around the world.

World view matters. It alters what tools a person or an organization uses and how they use them. As Astley (1985) states, "No theory can simply 'describe' empirical reality in neutral linguistic terms; all theoretical perspectives are infused by the biases inhering in particular world views" (p. 497). With this in mind, we look at how world view affects NGOs in Guatemala and the supply chains they employ.

We follow Ardalan's (2009) four classifications of world view: functionalism, radical humanism, radical structuralism, and interpretive, and the powerful impact world view has on 
perceptions of globalization. We saw the same mechanisms at work in the work of NGOs and the structure of their supply chains in Guatemala. The clashes were often present, but rarely open. Often, the primary participants in the clashes were not even aware of their differences.

As shown in Figure 1, each world view makes fundamental assumptions about the nature of science (the subjective-objective dimension on the vertical axis) and the nature of society (the regulation-radical change dimension on the vertical axis) (Ardalan, 2009; Burrell and Morgan 1979).

\begin{tabular}{|c|c|c|c|}
\hline \multicolumn{4}{|c|}{ The Sociology of Radical Change } \\
\hline \multirow{2}{*}{ 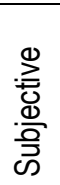 } & Radical Humanist & Radical Structuralist & \multirow{2}{*}{ 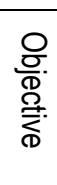 } \\
\hline & Interpretive & Functionalist & \\
\hline The & of Regulation & & \\
\hline
\end{tabular}

The nature of science includes assumptions of ontology, epistemology, human nature, and methodology. Ontological assumptions consider the nature of the object being studied and whether it is external to human experience or inevitably part of it, that is, a product of the mind that observes the object. Epistemological assumptions are about how people understand the world, communicate knowledge, and whether knowledge can be acquired or must be experienced. Assumptions about human nature define the relationship between people and their environments and the degree to which they experience or create the environment. Assumptions about methodology define the extent to which the world can be measured objectively, or must inevitably be subjected to the mind doing the measurement (Ardalan, 2009).

Assumptions about the nature of society define the degree to which society is regulated or subject to radical change. Sociology of regulation explains society as unified and cohesive (Ardalan, 2009). "It focuses on the need to understand and explain why society tends to hold together rather than fall apart" (Ardalan, 2009, p. 2). The sociology of radical change explains society based on assumptions about structural conflict, modes of domination, and structural contradiction. Focusing on the deprivation of human beings, both material and psychic, and looking toward alternatives rather than the acceptance of status quo. These assumptions about the nature of science and society help to define four world views that radically affect the way humanitarian and disaster relief organizations perform, and more specifically the way they implement their supply chains and use their resources to deliver goods and services to their clients.

As a reminder, these world views may seem abstract and far removed from the practical world of entering markets around the world, particularly from a traditional international business perspective. They would seem to mean nothing to multinational enterprises (MNEs) or multinational NGOs, but this appearance is deceptive, and Guatemala offers the most recent, telling example. For example, the Central American
Free Trade Agreement (CAFTA-DR) has what critics call the "Monsanto Law." It essentially gives intellectual property rights to companies that genetically modify seeds, even if the modification was not theirs, but is merely closely related. The indigenous people of Guatemala have historically traded and developed their own seeds, and found this provision of CAFTA-DR especially troubling. While the law was to be enacted on September 26, 2014, the Guatemalan Peasant Indigenous Workers Movement (MSICG) presented a motion of general, complete unconstitutionality against the law. The Court responded by specifically ruling on Articles 46 and 55, suspending them on the grounds that both could lead to serious impacts for both the people and the country (Dworkin, 2014).

The indigenous people have a culturally embedded supply chain and attempting to ruin or disrupt their supply chain for seed resulted in massive protests, with between 40,000 and 120,000 people in the streets of Guatemala City to oppose the law. Just twelve days before the law was to take effect, it was suspended by the Guatemalan high court as a response to these protests. CAFTA-DR is a clear manifestation of the functionalist view of the world as described below, and the indigenous pushback clearly comes from one of the other perspectives, most likely the radical humanist perspective. The message to MNEs was simple, "leave our culture alone."

\subsection{Functionalism}

Functionalism assumes the world can be understood as objective and value-free, and that it is subject to the measurement tools applied to the natural sciences. It assumes society is explicable in measurable terms, that the way it holds together can be regulated and controlled, and that observers, scientists or not, can explain it without interference from their own biases. It assumes rationality for both the observer and society as it is observed and places great faith in social engineering as a path to reform. It uses biological and mechanical analogies to model and understand social phenomena. Functionalism is positivist and individualistic in its traditions (Ardalan, 2009). Functionalism is emphatically the dominant worldview for those who favor globalization and who seek to reshape the world in neoliberal economic terms. Thus, it is the dominant worldview in business.

\subsection{Radical Humanism}

Radical humanism criticizes the status quo, whatever it may be, and posits a sociology of radical change. It is subjectivist, stressing human consciousness and views society and its structures as at least potentially anti-human. It seeks to find ways for people to release themselves from the constraints imposed by society so they can reach their potential. It sees social structures as instruments of domination, emancipation, deprivation, and potential - that is, working both for and against humanity. It seeks social change through changes in consciousness, and is fundamentally a subjectivist worldview. It is holistic, seeing society as an agglomeration of interdependent parts that are difficult, if not impossible, to understand in parts. Consequently, seeking to 
understand the 'laws of motion' and other generalizations about society is a waste of effort (Ardalan, 2009).

Functionalism is the dominant worldview and radical humanism opposes the functionalism viewpoint's assumptions about the world. Radical humanists see functionalism as the principal theory behind restrictive and oppressive social structures; they attempt to apply a dialectical view of society in keeping with the German philosopher Hegel (Ardalan, 2009), but oppose the economic preoccupation of the Marxist. Radical humanists see major actors like national governments and multinational firms as acting against human interests through a structure that is greater than the sum of its parts, a system that is fundamentally imperialist, but fundamentally containing the elements essential to its own destruction (Ardalan, 2009). It looks at the surveillance society, the World Bank, and other related institutions as attempting to dominate and exploit developing countries and even the middle and working classes of developed societies. It opposes the Soviet view of the world as much as it opposes what it may view as Western Imperialism.

\subsection{Radical Structuralism}

Radical structuralism shares many radical humanist views including opposition to the exploitative status quo that humans need emancipation from current social structures, and that radical change is inherent in social structures. Radical structuralism even shares the notion that the social whole is greater than its parts, but differs from radical humanism in a key point. This view sees the social world, like the natural world, as having an independent existence that is subject to measurement and shares this perspective with functionalism. In this view, society is full of regularities and patterns that are subject to scientific explanation using the tools of natural science, just as with functionalism.

They differ from functionalists on another point: to understand the nature of knowledge in radical structuralism demands an understanding of social class structure. Radical structuralism argues that knowledge is class specific, determined by the place in the productive process. Knowledge differs in kind, depending on social class, and is produced by a social class for itself. So knowledge "formulates views of reality and solves problems from class points of view" (Ardalan, 2009, p. 4).

Radical structuralism is based on four central ideas: totality, structure, contradiction, and crisis. Totality means that "the parts reflect the totality, not the totality the parts" (Ardalan, 2009, p.4). Structure means that social relationships are configured in enduring, concrete facilities. Contradiction means that these structures contain the seeds of their own decline. Crisis means that society can eventually no longer contain its contradictions, so political and economic conflict will move it from one totality to another of a different kind (Ardalan, 2009).

\subsection{Interpretive}

Interpretive views see the world as both subjective and unregulated. In this view, social reality results from the subjective interpretations of individuals. Social reality exists outside the individual mind only to the degree that individuals share a network of subjective meanings and interpretations, and these make up the social world. The observer is inevitably a participant in this world. Therefore frame of reference matters. There is no objective, measurable reality or set of explicable, persistent structures. It does take the perspective of a regulated society, however, one that can be understood, but only from the subjective perspective, as experienced, not as measured from some external position. Meaning is found in social life by those who live in it. The interpretive view opposes the idea that tools of natural science will reveal social reality; rather, social reality can be understood by human beings through their minds and feelings, and the ways these minds and feelings are expressed. This means that cultural phenomena are the external expression of inner feelings (Ardalan, 2009).

\section{CLASHES IN WORLD VIEW}

These four major world views often clash in developing countries, and Guatemala is no exception. The clashes come in two forms. The first is predictable, a form expected from the outlines of the world views: large organizations from developed nations bring their cultural expectations and organizational practices into developing countries that share neither the culture nor the organizational practices. From a supply chain perspective, the developing nations lack the infrastructure, technology, and work skills that the larger organizations, or at least some of the people in them, expect based on their experiences 'back home,' wherever that may be.

The second form comes from deep-seated differences in the education of NGO staffers from developed countries, especially the U.S., and the disciplines they study. Many come from backgrounds in community development, international relations, language studies, and cultural studies (Abom, 2004). They, and the professors who taught them, start from a perspective that is profoundly biased against the functionalist view of the world, one that they correctly associate with multinational businesses and multinational organizations like the World Bank and the International Monetary Fund. But, by association, these viewpoints carry over to the tools used by functionalist-oriented organizations, notably the tools of supply chain management and logistics. This means that the tools, associated with a nefarious world view, are ignored or not used, not because they will not contribute to the purpose of the NGO in question, but because they are associated with the powerful forces of globalization, forces that in some views are inhumane or possibly disrespectful of target cultures.

This kind of clash of world views is hardly new. In Americanism: A World Menace (1922), W. T. Colyer outlined the principles of Americanism, which he clearly put in the same category as Bolshevik Communism, as something to concern other cultures, and as designed to take over those cultures. He was a British labor leader who had lived in the United States for more than ten years. Colyer's (1922) 
description of Americanism fits well with functionalism, and one can argue that modern functionalism is a philosophical descendant of Americanism. Americanism stresses individualism, anti-intellectualism, and profits and revenues over people and cultures. The counter functionalist world views would define functionalism in much the same way. But what is the impact of this clash of world views on NGOs and their supply chains? From our interviews, what emerged was the idea that many NGO workers had little knowledge of supply chain management and logistics principles. The ideas were clearly novel to them, yet some applied those principles in effective but often disorganized ways.

Another lesson is often missed by the business or functional perspective: developing nations already have supply chains. They just do not look like or behave like the supply chains of developed nations. Supply chains are a part of the world, a part that is experienced in much the same way as other parts of the world. In Antigua, Guatemala, a vendor may sell small bottles of milk from a shelf-like rack that hangs from his neck. He is part of a supply chain, just not part of the kind of supply chain we usually see in developed nations. But in many instances neither the NGOs nor the MNEs use the existing supply chains that are thoroughly embedded in the local culture. This applies not only to Guatemala, but also to many developing nations.

Some businesses are certainly exceptions to this broad statement; Coca Cola uses carts that can be pulled by goats, bicycles, donkeys, or people as part of its delivery system in many parts of the world. Wal-Mart bought their way into Guatemala because executives realized they lacked understanding of Guatemalan supply chains. They bought an existing, successful retail firm name and it will be gradually transformed by Wal-Mart's considerable competence in this arena. But this transfer will be influenced heavily by the existing supply chain in Guatemala, creating a highly functional hybrid. This is a lesson that many NGOs in Guatemala must learn.

The research begins with a description of business and NGO supply chains. Figure 2 depicts three basic flows in a traditional supply chain: products flow from the factory toward the consumer, money flows from the consumer toward the factory, and information flows in both directions. While this is a greatly simplified model of a modern IT-assisted supply chain, it mirrors the purpose of this analysis, which is to contrast business supply chains with NGO supply chains.

Figure 3 outlines an NGO supply chain, based in part on the research conducted in Guatemala. It differs from the business supply chain on several points. First, it must market itself backward through the supply chain to attract money, materials, supplies, and even labor. Second, NGO activities are themselves less likely to be major sources of income, although many do charge at least nominal fees for their services and products, or clients can pay for these in kind or with their own labor. Third, NGOs often tightly control the flow of backward information to donors and suppliers. This becomes an administrative process that may interfere with the understanding that donors, in particular, have of the NGOs activities. The administration acts as a filter for information, good or not.

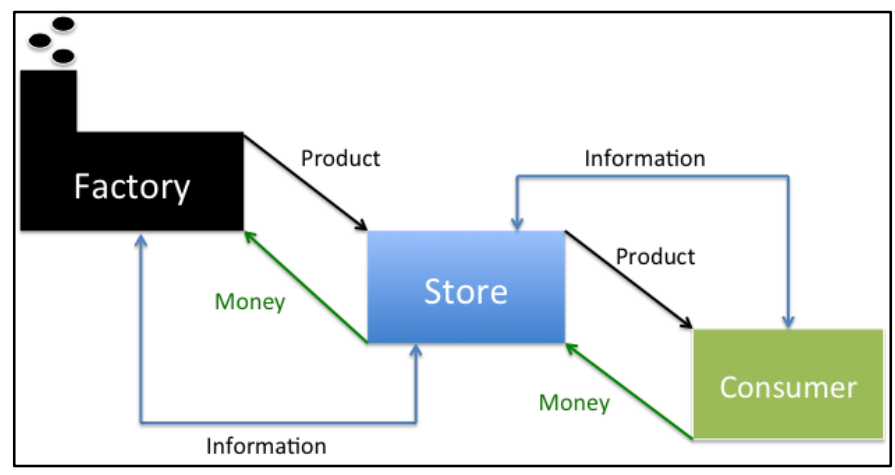

Figure 2 Traditional For-Profit Supply Chains

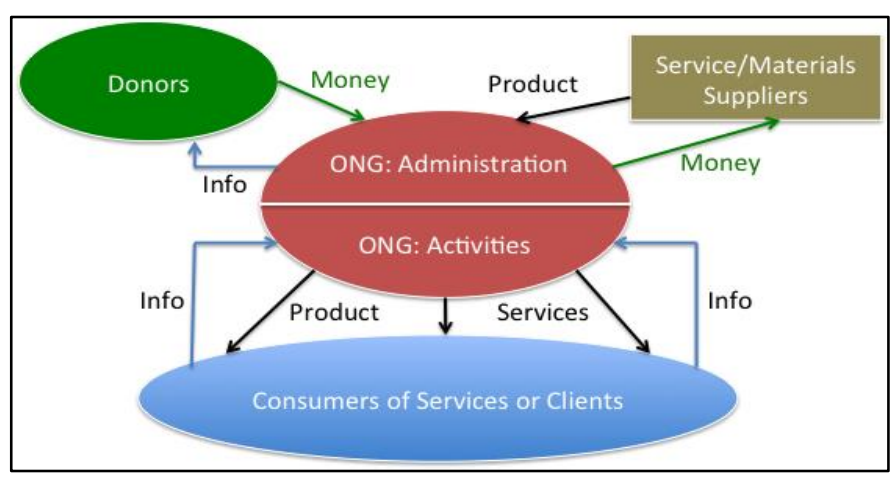

Figure 3 Typical NGO Supply Chain

NGO supply chains often include a supply of specific labor. The labor may come from people with skills and abilities not readily available in the client country, for example, specific engineering or medical skills. Labor comes from volunteers, people with no specific skill set, but with the time, money, and heart available to serve. On one hand, Guatemalans have a mixed view of volunteers for NGOs. They appreciate their work, but they see a lack of competence, commitment, and cultural understanding in many of the volunteers. Some volunteers fit a pejorative description of the word "voluntourist," people who come one time, congratulate themselves for whatever they have done, and figuratively, if not literally, don the tee shirt that says "Been there, done that." They work on a project, stay a few days, then leave, never to return. Many Guatemalans view this negatively, particularly as lacking in commitment to their country and their culture.

One well-documented example of this comes from Zambia, not Guatemala. Many organizations distribute pesticide-treated mosquito nets. The nets are intended to protect people from mosquitoes as they sleep, but many of them are turned into fishing nets instead. The donors of these nets mean well, but they do not have the same priorities as the recipients; the recipients need food to avoid starvation more than they need nets to prevent malaria. If they starve, malaria is not an issue. This has created two other unintended consequences. First, treated mosquito nets have become a 
major industry in Africa. Second, because those nets were designed to keep out tiny creatures, using them as fishing nets takes so much life out of the water that it has become and environmental issue (Gettleman, 2015)

A situation that is less easy to confirm, but also illustrative, comes from Guatemala itself. According to persistent but unconfirmed reports, one NGO went to a remote village in Guatemala to help build and install water filtration systems, since the water supply was contaminated. The villagers were taught how to maintain and use the system. The NGO volunteers left, feeling that they had accomplished something important. But the villagers dismantled the filtration systems almost immediately. The systems were made in part of sheet metal, a kind that could easily be used to patch leaky roofs around the village. The leaky roofs were a greater problem in the minds of the villagers than the lack of clean water. While this remains unconfirmed, its persistence among NGO workers in Guatemala, and among some of their clients, is revealing. At the least, many see the NGOs as misguided and as less concerned with the priorities of the people they purport to serve.

On the other hand, many NGOs see "voluntourism" as an essential part of their operating model. First, some volunteers return often, work on multiple projects, and commit personal time and money to work on the tasks associated with the NGO. Second, even one time visitors and dabblers may become more engaged with the organization and subsequently donate more time, money, and other resources to the cause. It may be as simple as talking up the organization to their friends, both in person and through social media. So the NGOs must balance their reputations among clients, which may be damaged by incompetent or insensitive volunteers, against the possibility that these same volunteers will add to the body of resources that the organization needs.

The researchers on this project experienced this directly with comments from the NGOs including, "You won't be back," "You won't stay," and "You're still here? Wow!" The reputation and likely success or survival of an NGO is tied to the need for commitment and caring. Both are clearly embedded in the minds of Guatemalans, whether clients or not.

\section{METHODOLOGY}

This research was ethnographic, historiographic, and qualitative. Fundamentally, it was a process of collecting and analyzing stories from a range of NGO officials, clients, and Guatemalans. It was chosen as the most appropriate methodology since it describes how a cultural group functions and is a way to explore their behaviors as well as issues faced by the group. The fieldwork collects information in the setting where the group works (Creswell, 2012). The results are in no way generalizable statistically, but did lead us to propositions and to directions for further research. Table 1 summarizes the steps conducted during the research process.

Table 1 Steps in the Ethnographic and Historiographic Research Process

\begin{tabular}{|c|c|c|c|}
\hline 1. & \multicolumn{3}{|c|}{ Principal researcher with supply chain background moved to Guatemala following completion of MBA } \\
\hline 2. & \multicolumn{3}{|c|}{$\begin{array}{l}\text { Principal researcher recruited second expatriate researcher from the US who had lived in Guatemala for three years and } \\
\text { worked with a number of NGOs }\end{array}$} \\
\hline 3. & \multicolumn{3}{|c|}{ Researchers completed and received study approval to investigate the Guatemalan NGOs as part of the university IRB process } \\
\hline 4. & \multicolumn{3}{|c|}{$\begin{array}{l}\text { Principal researcher studied Spanish extensively while visiting and working with NGOs over one year and developed the "To- } \\
\text { For-With" Framework in conjunction with his work and language training }\end{array}$} \\
\hline 5. & \multicolumn{3}{|c|}{$\begin{array}{l}\text { US-based logistics and supply chain business faculty visited Guatemala to interview leaders of key NGOs with aid of translators } \\
\text { in open-ended format }\end{array}$} \\
\hline 6. & \multicolumn{3}{|c|}{$\begin{array}{l}\text { Guatemalan based researchers continued ongoing interviews in Spanish with various NGOs found through their work and } \\
\text { through recommendations from translators and other contacts in a "snowball" sampling methodology }\end{array}$} \\
\hline 7. & \multicolumn{3}{|c|}{$\begin{array}{l}\text { Resident researchers transcribed taped interviews with the NGO participants in Spanish and back translated the text into } \\
\text { English }\end{array}$} \\
\hline 8. & \multicolumn{3}{|c|}{$\begin{array}{l}\text { Separately all researchers analyzed the data from the fieldwork for a description of emerging themes and overall interpretation } \\
\text { (Wolcott, 1994). }\end{array}$} \\
\hline 9. & \multicolumn{3}{|c|}{$\begin{array}{l}\text { Researchers developed criteria and variables for classifying the } 13 \text { NGOs from independent and then group agreement of the } \\
\text { phenomenological interviews. The nine criteria emerging from the research included: }\end{array}$} \\
\hline 10. & $\begin{array}{l}\text { 1) goal congruence } \\
\text { 2) knowledge of first } \\
\text { priority needs } \\
\text { 3) bilateral, unfettered } \\
\text { communication }\end{array}$ & $\begin{array}{l}\text { 4) action performed } \\
\text { 5) residual intelligence } \\
\text { 6) post-hoc deployment } \\
\text { support }\end{array}$ & $\begin{array}{l}\text { 7) on-going relationships 8) contextually } \\
\text { sensitive } \\
\text { 9) collaboration }\end{array}$ \\
\hline 11. & \multicolumn{3}{|c|}{$\begin{array}{l}\text { Together the research team classified the } 13 \text { NGOs into the To-For-With Framework using the nine criteria resulting from the } \\
\text { data collected }\end{array}$} \\
\hline
\end{tabular}


Specifically, two of the researchers have lived and worked in Guatemala for more than a year and are thoroughly acquainted with this area; one already lived in the area and joined the project later; the second moved there explicitly to carry out the project. Two other researchers visited the country to interview officials at NGOs in Antigua and Guatemala City, Guatemala. The five principal researchers have conducted dozens of interviews with NGO workers and clients, worked for NGOs in Guatemala and the United States, analyzed NGO supply chains in multiple countries, and researched disaster supply chain logistics.

First, we conducted informal, preparatory interviews with NGO officials in Guatemala, primarily seeking their insights and soliciting them to participate in the research. The two resident researchers live in Guatemala and work closely with NGOs in Antigua and Guatemala City; they are fluent in Spanish as a second language. Second, we conducted formal, structured interviews with officials from thirteen NGOs. Two U.S. based researchers joined the team in Guatemala to carry out interviews at the three NGOs used extensively as examples in this analysis. The two resident researchers acted as interpreters for these interviews, maintaining the integrity of the interviewing process. Third, we conducted follow up interviews with each NGO to strengthen our research and expand our knowledge. Fourth, we devised the To-For-With Framework explained below, and fifth, from the interviews, we developed nine criteria for placing NGOs and their supply chains into one of the three (To, For, and With) framework classifications.

\section{THE TO-FOR-WITH FRAMEWORK}

In this research, we classified a convenience sample of 13 NGOs as either "TO," "FOR," or "WITH" organizations within our To-For-With Framework. In this section, we describe each of the three classifications from the framework (To, For or With). We also present and define the nine criteria that emerged from the ethnographic research. We used these criteria to assess and assign organizations to one of the three classification categories. We briefly describe each organization in its own terms, as well as in the terms of the criteria. First is a description of the model's classifications to determine if an NGO's status is "To," "For," or "With." We include an explanation for how the framework was developed.

One of this study's researchers had returned to Guatemala to study Spanish and explore the possibilities for building a career and for doing good, specifically helping Guatemalans do better for themselves. As he immersed himself in the Spanish language, he immersed himself in Antigua, Guatemala and quickly realized business skills were in short supply and were seldom applied to the businesses and non-profits in the area. It was not for lack of interest, but for lack of knowledge. He found his Spanish lessons to be an object lesson in another sense. When he attempted to explain his interest in supply chains to his language instructors, it was difficult to get across the idea 'supply chain' to the instructors.
After a few days of struggling with it, the words came out as 'cadena de los recursos' or "chain of resources," and after conversations with business students who had studied in Guatemalan universities, these were the words they used too. He considered supply chains, NGOs, and the likely success of both in Guatemala. In his Spanish class, as he practiced using the Spanish words 'a,' 'para,' and 'con' or, in English, 'to', 'for', and 'with.' In his mind, he could classify NGOs by whether they did things to Guatemalans, for Guatemalans, or with Guatemalans. The foundation for the success of any organization would differ greatly from one category to another. And this became the classification framework for NGOs.

\subsection{TO Organizations}

"TO" organizations are task oriented, ignore context, and ignore people. They approach clientele with preconceived notions of both the problem and the necessary solutions, often without knowing or having contact with the clients or the culture involved. The people and the cultural context are secondary to the task. For the most part, TO organizations are only sustainable through continuous external funding, external staffing, and external motivation. TO organizations tend to be short-lived, largely because of supply chain issues. Many religious missions fall into this category. They mean to convert Guatemalans to their beliefs but can only sustain their operations with continuous, external funding.

\subsection{FOR Organizations}

"FOR" organizations still maintain a task or project orientation, but they have usually defined the task in the context of the culture and the clientele. That is, they set out to do something of value for their clients. But they still value process and project over people and context. Their approach tends to rely on their own expertise and usually fails to transfer that expertise to the clients or to the client culture and context. It is, in many ways, a paternalistic view of the project and the clients. FOR organizations are often sustainable because they have accomplishments they can relay to donors. They still tend to rely heavily on outside sources of money and people. Locals from the client culture tend to hold lower-level positions in the organizations and to have a slight influence on the operations and policies of the organization.

\subsection{WITH Organizations}

"WITH" organizations develop long term relationships with people in the client cultures and help the client cultures develop the knowledge, skills, and abilities to solve their own problems. WITH organizations may arise from the indigenous population, setting aside the issue of shared goals. The outside organization working in the WITH environment 
has as one of its long term goals to go out of business and the outsider is no longer needed to accomplish the organization's stated mission or goals because the client population takes over. WITH organizations have people from the client population in positions of authority, receive material support from client cultures and populations, and coordinate activities based on indigenous supply chains, infrastructure, and facilities. WITH organizations build capacity in physical and human capital.

\section{NINE CRITERIA FOR CLASSIFYING NGOS IN THE TO- FOR-WITH FRAMEWORK}

The nine criteria include: 1) goal congruence; 2) knowledge of first priority needs; 3) bilateral, unfettered communication; 4) action performed; 5) residual intelligence; 6) Post-hoc deployment support; 7) on-going relationships; 8) contextually sensitive; and finally 9) collaboration. The nine criteria emerged from the research. We did not draw them from prior research. Rather, a combination of officials from these organizations and their clients tell us what the criteria should be. The multi-method approach used in data collection helped to develop the assessments. If others replicate the results, however, we would expect fairly high levels of inter rater consistency.

These are the criteria used to classify the thirteen organizations included in this research. We established specific standards for classifying an organization as TO, FOR, or WITH. Essentially, to be classified WITH, an organization must get a 'yes' on all of the nine criteria. The role of supply chains change as organizations evolve from the FOR to the WITH classification. With a few exceptions, TO organizations rarely evolve at all. Their supply chains are sustained from the outside, or are as ephemeral as the organizations themselves. We have yet to identify an exact point where the supply chain supports WITH versus FOR. Currently, each organization has their own answers to the problems inherent in setting up a supply chain. In discussing these criteria, we note whether they come primarily from a business perspective or from an NGO perspective, but most of the definitions and explanations below are hybrids of the two.

\subsection{Goal Congruence (Business)}

This is primarily a business term, often applied in situations where organizations must cooperate-in supply chains, for example. In businesses and in many large organizations, goals are set by people at or near the top and handed down. This is intended to assure that goals fit at every level of the organization and the same applies across functions and divisions. Customers influence but do not participate in goal setting. In the NGO environment, the needs and the goals for satisfying those needs are, or should be, determined by the clients. It is important for the NGO's goal to run in tandem with the community's, so goal creation will arise from clients; top down goal setting works only rarely in this circumstance, and then only by coincidence. Goal setting helps determine the nature of the NGO supply chains. Goal congruence helps to determine whether the supply chains deliver the right goods, services, and people to meet the clients' needs.

\subsection{Knowledge (Understanding) of First Priority Needs (NGO)}

This notion comes primarily from the NGO perspective. Again, customers may influence business goals and priorities, but in the NGO environment, clients should not only set the goals, but should order goals as a precondition for success. Here, needs are characterized as nutrition, housing, clean water, education, and other necessities. They are the very building blocks of a society or even existence. However, allowing clients to decide these first priority needs suggests the community typically has a good idea of top priorities for assistance. Goal congruence is an overall organization-tocommunity agreement of purposes, but a community's first priority may not be what NGO workers and leaders think it is or should be. The community may lack clean water, but at the time of the NGO intervention, may want roofs instead.

\subsection{Bilateral, Unfettered Communication (Business/Listening (NGO))}

Each NGO should have at least one person who can communicate between international and local partners. That means, for example, having at least one a bilingual person on staff, but understanding this is necessary, but not sufficient for proper functioning. In reality, there can be any number of bilingual people involved, but real communication never occurs, so goal congruence and knowledge of the first priority needs often breaks down. Bilateral communication supports goal congruence about changing priorities. Thus as one goal is met, another moves to the top priority list. Circumstances can change radically. For example, a drought may change priorities, moving irrigation systems to the forefront. If organizations receive money or donations from inside the country, then there is little need for bilingual skills, however, for most NGOs in Guatemala, the money comes from external donors, which leads to a demand for bilingual workers.

\subsection{Action Performed (Business/NGO)}

An NGO must do something, and action should at least resemble the organization's stated purpose. While this existentialism may seem obvious, there are a number of nonorganizations in Guatemala, organizations that are just ideas with no presence beyond that. This criterion eliminates those organizations from consideration. 


\subsection{Residual Intelligence/Shared Intelligence/Transfer of Intelligence (Business) - Capacity Building (NGO)}

This component remains after the NGO intervenes. Is there some new capacity that the affected population can use? Is the action performed just a hand-out and not a hand-up? For an NGO to put itself out of business, their actions must be conducted to eventually prepare the affected population to take over the activity, the facility, or even the organization. For example, this can be a physical facility, but the capacity must include the knowledge of how to manage, maintain, upgrade, and replace the facility. Without the transfer of human and physical capacity, relief never shifts to development, and the cycle of poverty or other identified problem can continue forever. This criterion is similar to the ideas outlined in Day et al. (2012).

\subsection{Post-Hoc Deployment Support (D) - Continuing Monitoring and Evaluation (E)}

In the latter phases of the deployment of a humanitarian disaster relief supply chain (HDRSC), taking on a passive role (or planning for one) is paramount to secure real development. Most organizations never undertake a post-operation review of aid and its effects. Thus, the combined activity of supporting passively in the post-hoc period should include a monitoring and evaluation component.

\subsection{On-Going Relationships (Business)}

A major problem is that outsiders and NGOs come and go quickly. The international volunteers often come once but never return. The NGOs arrive, spend their limited budgets, and then vanish. These operations work for short-term disasters, but not for slow developing problems of poverty, endemic health problems, or drought. Developing an on-going relationship is important to ensure continued support, work, and future interventions. It is essential to making the transition from relief to development. Handing out food following a disaster is one thing, but building the infrastructure to support wealth and to reduce the need for disaster relief in the future is another. Without this continuity, the initial intervention is likely to fail because it did not meet the community's goals of long-term survival.

\subsection{Contextually Sensitive (NGO)}

Ignoring social norms and mores is no way build a "With" organization. Culture is context. Those individuals and organizations who marginalize the people they seek to help makes it likely they will not only fail to help their clients, they will make it more difficult for others to help. They effectively create bad will and stereotypes that work against the next group of would-be helpers.

\subsection{Collaboration (NGO)}

This criterion is about accomplishing the organization's mission, not protecting the organization's turf or hiding in its silo. There are typically a number of NGOs operating in the same space doing the same thing. Collaboration is a willingness to partner with other NGOs to reach common goals and to serve the client community. Some NGOs in Guatemala are territorial, seeking to build their organization, their reputation and influence, or their donor pool. When organizations lack the willingness to collaborate, then the cost of HDRSCs rises.

We considered an exit plan, an asset based approach, and accountability to the local community as additional criteria for our framework, but found them to be redundant or overlapping some combination of the included criteria. For example, accountability to the local community is covered by contextual sensitivity. Goal congruence, an exit plan by ongoing relationships and post-hoc deployment support, and the asset-based approach is addressed both by goal congruence and first priority needs.

We applied the criteria to classify the snowball sample of 13 NGOs as shown in Table 2. The table, however, does not include names of the NGOs or other identifying information. Brief descriptions of all 13 can be found in Table 3.

We interviewed more than 40 officials in 13 NGOs, dozens of clients of NGOs in Guatemala, and numerous Guatemalans on their attitudes toward NGO presences in Guatemala. In a few instances, interviews were recorded, and all were accompanied by extensive note-taking and observations following a pre-determined initial set of questions such as "Where do you get the supplies that allow you to operate? How do your clients get access to your products or services?" Since we have continuous, unrestricted access to our sources, we found recording devices to be inhibiting and added little value. In each of the formal interviews, subjects were questioned extensively regarding their supply chains and understanding supply chains as well as logistics principles.

In sum, the methods for this portion of this extended project were ethnographic and historiographic. We assessed the NGO supply chains and supply chain readiness of NGOs in Guatemala in a qualitative setting. Details are in the following sections. This research is based entirely on public statements by NGO officials and publicly available information, along with informal opinions and views expressed by unidentified individuals. Following our university IRB protocol, no data were gathered about the individuals interviewed in the Guatemalan NGOs, nor do we identify anyone in anyway other than in their official capacity. 
LeMay et al. : World Views and the Evaluation of NGO Supply Chains: Thirteen Cases from Guatemala

Operations and Supply Chain Management 9(2) pp. 90 - 104 () 2016

99

Table 2 The 13 Guatemalan NGO'S Classified in the TO-FOR-WITH framework

\begin{tabular}{|c|c|c|c|c|c|c|c|c|c|c|c|c|c|}
\hline \multirow{2}{*}{$\begin{array}{l}\text { Nine Criteria for } \\
\text { Classification }\end{array}$} & \multicolumn{13}{|c|}{ The 13 NGOs in Guatemala } \\
\hline & 언 & $\begin{array}{l}\sim \\
\text { O̊ } \\
2\end{array}$ & ○్ & $\begin{array}{l}+ \\
\text { O্ } \\
2\end{array}$ & م & $\begin{array}{l}0 \\
\text { 일 }\end{array}$ & 엉 & \begin{tabular}{l}
$\infty$ \\
\hdashline \\
\hdashline
\end{tabular} & $\begin{array}{l}0 \\
0 \\
0\end{array}$ & $\begin{array}{l}\text { 음 } \\
\text { 인 }\end{array}$ & হ & 웅 & $\frac{m}{\grave{0}}$ \\
\hline Goal Congruence & $Y$ & $Y$ & $Y$ & $\mathrm{Y}$ & $\mathrm{N}$ & $\mathrm{Y}$ & $\mathrm{Y}$ & $Y$ & $\mathrm{Y}$ & $\mathrm{Y}$ & $\mathrm{Y}$ & $Y$ & $\mathrm{Y}$ \\
\hline $\begin{array}{l}\text { Knowledge of } \\
\text { First Priority } \\
\text { Needs }\end{array}$ & N & Y & $Y$ & Y & N & Y & Y & Y & Y & Y & Y & $Y$ & $\mathrm{~N}$ \\
\hline $\begin{array}{l}\text { Bilateral, } \\
\text { Unfettered } \\
\text { Communication }\end{array}$ & $\mathrm{N}$ & Y & $\mathrm{N}$ & Y & $\mathrm{N}$ & Y & Y & Y & Y & Y & Y & Y & Y \\
\hline Action Performed & $\mathrm{Y}$ & $Y$ & $Y$ & $\mathrm{Y}$ & $\mathrm{Y}$ & $Y$ & $Y$ & $Y$ & $Y$ & $Y$ & $\mathrm{Y}$ & $Y$ & $Y$ \\
\hline $\begin{array}{l}\text { Residual } \\
\text { Intelligence }\end{array}$ & Y & Y & $Y$ & Y & $\mathrm{N}$ & $\mathrm{N}$ & Y & Y & Y & Y & Y & Y & Y \\
\hline $\begin{array}{l}\text { Post-Hoc } \\
\text { Deployment } \\
\text { Support }\end{array}$ & Y & Y & Y & $\mathrm{N}$ & $\mathrm{N}$ & $\mathrm{N}$ & Y & Y & $\mathrm{N}$ & $\mathrm{N}$ & Y & $\mathrm{N}$ & Y \\
\hline $\begin{array}{l}\text { On-Going } \\
\text { Relationship }\end{array}$ & Y & Y & $\mathrm{N}$ & Y & $\mathrm{N}$ & $\mathrm{N}$ & Y & Y & Y & Y & Y & $\mathrm{N}$ & $Y$ \\
\hline $\begin{array}{l}\text { Contextually } \\
\text { Sensitive }\end{array}$ & Y & Y & Y & Y & $\mathrm{N}$ & $Y$ & Y & Y & $Y$ & $Y$ & $Y$ & $Y$ & $Y$ \\
\hline Collaboration & $Y$ & $Y$ & $Y$ & $Y$ & $\mathrm{~N}$ & $\mathrm{~N}$ & $\mathrm{~N}$ & $Y$ & $Y$ & $Y$ & $Y$ & $Y$ & $Y$ \\
\hline Classification & FOR & WITH & FOR & FOR & TO & FOR & FOR & WITH & FOR & FOR & WITH & FOR & FOR \\
\hline
\end{tabular}

Table 3 Brief Description of the 13 NGOS

\begin{tabular}{|c|c|c|c|c|}
\hline & NGO name & NGO's Mission & History & Results \\
\hline 1 & $\begin{array}{l}\text { Corazon de los } \\
\text { Ninos }\end{array}$ & $\begin{array}{l}\text { Provide services and } \\
\text { programs for poor } \\
\text { children, youth, and } \\
\text { families }\end{array}$ & $\begin{array}{l}\text { Started addressing lack of } \\
\text { school attendance for children } \\
\text { and has grown to meet family } \\
\text { needs over a } 20 \text { year history } \\
\text { growing as local needs were } \\
\text { uncovered }\end{array}$ & $\begin{array}{l}\text { Specific services includes nutrition security, infant } \\
\text { stimulation for cognitive development, primary } \\
\text { education, childhood educational support, and basic } \\
\text { health services (medical, dental, psychological } \\
\text { counseling, laboratory health services, and a } \\
\text { pharmacy) }\end{array}$ \\
\hline 2 & $\begin{array}{l}\text { US-Based } \\
\text { Religious } \\
\text { Organization } \\
\text { (Unnamed) }\end{array}$ & $\begin{array}{l}\text { They printed up flyers on } \\
\text { a literacy program that } \\
\text { they planned to start and } \\
\text { translated the flyers into } \\
\text { Spanish. They gave the } \\
\text { flyers to the children who } \\
\text { could not read to take } \\
\text { home to their parents, } \\
\text { forgetting that the parents } \\
\text { probably could not read } \\
\text { either. }\end{array}$ & $\begin{array}{l}\text { A couple from a New England } \\
\text { church visited Guatemala on } \\
\text { an unrelated project, but } \\
\text { noticed that many of the } \\
\text { children involved in the project } \\
\text { were illiterate }\end{array}$ & $\begin{array}{l}\text { They failed to take into consideration the } \\
\text { circumstances in which the prospective clients found } \\
\text { themselves. So this NGO never materialized. }\end{array}$ \\
\hline 3 & $\begin{array}{l}\text { Sonidos Para } \\
\text { La Vida }\end{array}$ & $\begin{array}{l}\text { Accomplish change by } \\
\text { teaching music and } \\
\text { providing children from } \\
\text { disadvantaged } \\
\text { backgrounds with goals. }\end{array}$ & $\begin{array}{l}\text { Started as a church initiative } \\
\text { in } 1978 \text { and quickly expanded } \\
\text { outside the church home to a } \\
\text { number of rural communities } \\
\text { teaching some } 2,200 \\
\text { students. }\end{array}$ & $\begin{array}{l}\text { While not a first priority need, the impact of music } \\
\text { education and related services proved very important. }\end{array}$ \\
\hline 4 & $\begin{array}{l}\text { Behrhorst } \\
\text { Partners for } \\
\text { Development }\end{array}$ & $\begin{array}{l}\text { Started with a goal to } \\
\text { address community } \\
\text { health and development } \\
\text { founded by an American } \\
\text { citizen }\end{array}$ & $\begin{array}{l}\text { Started in } 1967 \text { and has } \\
\text { implemented water and } \\
\text { sanitation as well as food } \\
\text { security and family planning } \\
\text { programs. }\end{array}$ & $\begin{array}{l}\text { Shifted to mostly Guatemalan staff and changed } \\
\text { priorities to reduce childhood hunger and malnutrition. }\end{array}$ \\
\hline
\end{tabular}


Table 3 Brief Description of the 13 NGOS (con't)

\begin{tabular}{|c|c|c|c|c|}
\hline 5 & $\begin{array}{l}\text { Instituto } \\
\text { Mesoamericano } \\
\text { de } \\
\text { Permacultura }\end{array}$ & $\begin{array}{l}\text { IMAP is a Guatemalan- } \\
\text { founded and led NGO } \\
\text { that receives international } \\
\text { and national volunteers } \\
\text { depending on interest } \\
\text { and fit. }\end{array}$ & $\begin{array}{l}\text { Founded in } 2000 \text { by locals } \\
\text { concerned by the serious } \\
\text { environmental, social, political } \\
\text { and cultural problems } \\
\text { affecting Mesoamerican } \\
\text { communities }\end{array}$ & $\begin{array}{l}\text { Evolved and changed its program focus based on } \\
\text { local needs and its own organizational capacity. }\end{array}$ \\
\hline 6 & Let's Be Ready & $\begin{array}{l}\text { Acknowledges } \\
\text { deficiencies in the } \\
\text { Guatemalan education } \\
\text { system and addresses } \\
\text { the lack of effective early } \\
\text { childhood and preschool } \\
\text { education. }\end{array}$ & $\begin{array}{l}\text { Founded in } 2008 \text { by an } \\
\text { American citizen to address } \\
\text { semi-rural and sometimes } \\
\text { urban populations to break the } \\
\text { poverty cycle through } \\
\text { improved education. }\end{array}$ & $\begin{array}{l}\text { Is run by Guatemalan-locals. Their nutritional program } \\
\text { is funded largely by private foundations, while the } \\
\text { teacher component is dependent almost entirely on a } \\
\text { yearly recurring sponsorship model between a given } \\
\text { teacher/community and individual donor. }\end{array}$ \\
\hline 7 & Semilla Nueva & $\begin{array}{l}\text { Developing rural } \\
\text { Guatemala is their goal } \\
\text { where farmers have } \\
\text { harnessed the power of } \\
\text { new sustainable } \\
\text { agriculture technologies, } \\
\text { community organization, } \\
\text { and engagement with } \\
\text { local government. }\end{array}$ & $\begin{array}{l}\text { Founded in } 2010 \text {, they are a } \\
\text { sustainable agricultural- } \\
\text { focused NGO working directly } \\
\text { with farmers }\end{array}$ & $\begin{array}{l}\text { In year five of generally successful trials with their } \\
\text { educational model and promoted crops, the SN team } \\
\text { realized cooperation between their organization and } \\
\text { local, national and regional institutions was needed to } \\
\text { achieve a long-term impact. }\end{array}$ \\
\hline 8 & $\begin{array}{l}\text { Habitat for } \\
\text { Humanity } \\
\text { Guatemala }\end{array}$ & $\begin{array}{l}\text { Like its affiliate in the US, } \\
\text { HFHG works to ensure } \\
\text { dignified housing to those } \\
\text { in need through a variety } \\
\text { of programs and } \\
\text { approaches. }\end{array}$ & $\begin{array}{l}\text { Worked in Guatemala since } \\
1979 \text {, making Guatemala its } \\
\text { oldest currently active } \\
\text { international affiliate }\end{array}$ & $\begin{array}{l}\text { With coverage throughout all } 22 \text { departments of the } \\
\text { country and already } 312,000 \text { people served, HFHG's } \\
\text { scale and breadth is unlike other local NGOs. In the } \\
\text { last decade, HFHG has seen both their number of } \\
\text { employees and families served double. }\end{array}$ \\
\hline 9 & $\begin{array}{l}\text { The Ripple } \\
\text { Effect Inc }\end{array}$ & $\begin{array}{l}\text { TRE aims to improve the } \\
\text { long-term quality of life } \\
\text { within its partner } \\
\text { communities by } \\
\text { development projects } \\
\text { conceived, designed and } \\
\text { implemented in a holistic } \\
\text { fashion. }\end{array}$ & $\begin{array}{l}\text { Work exclusively in the } \\
\text { impoverished and isolated } \\
\text { region of Chajul in the Quiche } \\
\text { department since } 2006\end{array}$ & $\begin{array}{l}\text { TRE had added additional staff over the years as it } \\
\text { has transitioned towards a more formal entity. TRE } \\
\text { remains a venture almost entirely dependent on the } \\
\text { activity of its American founder. }\end{array}$ \\
\hline 10 & $\begin{array}{l}\text { The } \\
\text { Doppenbergs in } \\
\text { Guatemala } \\
\text { (The DIG) }\end{array}$ & \begin{tabular}{l}
\multicolumn{1}{c}{ To work } \\
toward abolishing \\
malnourishment in \\
Guatemala by addressing \\
immediate need and then \\
helping people become \\
self-sustaining through \\
education and \\
empowerment, and 2) To \\
work together with people \\
in North America to \\
empower their hearts \& \\
minds for service in \\
developing nations so \\
together we can make \\
this world a better place."
\end{tabular} & $\begin{array}{l}\text { Founded by a family of } \\
\text { Canadian missionaries with } \\
\text { extensive NGO volunteer } \\
\text { experience in Guatemala, the } \\
\text { DIG is founded in response to } \\
\text { the lack of quality NGO } \\
\text { attention devoted to the } \\
\text { southeastern region of Jutiapa } \\
\text { despite high levels of need } \\
\text { evident elsewhere throughout } \\
\text { the region. }\end{array}$ & $\begin{array}{l}\text { Current project areas include implementing the } \\
\text { holistically-oriented village education and } \\
\text { empowerment program in select communities, } \\
\text { supporting the ongoing work of a once fledgling area } \\
\text { pediatric malnutrition rehabilitation center, and the } \\
\text { recently inaugurated DIG Education Center and } \\
\text { Research Farm built to improve organizational } \\
\text { methods and practices. }\end{array}$ \\
\hline
\end{tabular}


Table 3 Brief Description of the 13 NGOS (con't)

\begin{tabular}{|c|c|c|c|c|}
\hline 11 & $\begin{array}{l}\text { Asociación } \\
\text { Nacional de } \\
\text { Bomberos } \\
\text { Municipales } \\
\text { (ASONBOMD) }\end{array}$ & $\begin{array}{l}\text { From acquiring and } \\
\text { distributing equipment to } \\
\text { government advocacy } \\
\text { ASONBOMD formed to } \\
\text { support supporting the } \\
\text { needs of member fire } \\
\text { stations. }\end{array}$ & $\begin{array}{l}\text { Founded in 2005, the } \\
\text { Guatemalan-led ASONBOMD } \\
\text { is an organization that sought } \\
\text { to provide support to the } \\
\text { already existing fire response } \\
\text { infrastructure of Guatemala. }\end{array}$ & $\begin{array}{l}\text { ASONBOMD brought about the consolidation of many } \\
\text { disparate, small voices into a coherent whole to work } \\
\text { with the government in securing firefighters' aims. }\end{array}$ \\
\hline 12 & $\begin{array}{l}\text { Asociación Pre- } \\
\text { Hospitalaria de } \\
\text { Guatemala }\end{array}$ & $\begin{array}{l}\text { Dual roles has led to a } \\
\text { weakening of the ability } \\
\text { of firefighters to do either } \\
\text { job as well as they could. } \\
\text { As such, the Guatemalan } \\
\text { Pre-Hospitalization } \\
\text { Association wanted to } \\
\text { help untether the roles } \\
\text { and create separate } \\
\text { positions for the } \\
\text { specialties. }\end{array}$ & $\begin{array}{l}\text { In Guatemala, the paramedics } \\
\text { are largely the firefighters. The } \\
\text { APHG was founded in } 2007 \\
\text { with the goals of training } \\
\text { paramedics and to enhance } \\
\text { triage response in Guatemala. }\end{array}$ & $\begin{array}{l}\text { The association accomplished their goals by offering } \\
\text { medical conferences and training sessions to improve } \\
\text { communities" triage and disaster response abilities. }\end{array}$ \\
\hline 13 & $\begin{array}{l}\text { Los Patojos } \\
\text { (The Children) }\end{array}$ & $\begin{array}{l}\text { To educate, our reason to } \\
\text { be: Childhood, our } \\
\text { strategy: To activate } \\
\text { dreams and ideas," is the } \\
\text { mission statement of Los } \\
\text { Patojos, an after-school } \\
\text { initiative that gives } \\
\text { children a place to go } \\
\text { after school. }\end{array}$ & $\begin{array}{l}\text { Founded in 2007, Los Patojos } \\
\text { is poised to receive the CNN } \\
\text { Heroes award } 2014 .\end{array}$ & $\begin{array}{l}\text { With a multi-pronged approach, Los Patojos provides } \\
\text { after-school support for education, nutrition, access to } \\
\text { health care, and access to cultural activities of art and } \\
\text { theatre. They serve } 150 \text { children of the Jocotenango } \\
\text { area with approximately } 30 \text { people supporting the } \\
\text { organization }\end{array}$ \\
\hline
\end{tabular}

\section{FINDINGS}

We classified one organization as "TO" in this research, a Faith Based Reading initiative that failed from its initial efforts. A couple from a New England church visited Guatemala on an unrelated project, but noticed that many of the children involved in the project were illiterate. They printed up flyers on a literacy program that they planned to start and translated the flyers into Spanish. They gave flyers to the children who could not read to take home to their parents, forgetting that the parents probably could not read either.

It is easy to understand why these well-meaning people sought to work on improving literacy in Guatemala. From an outsider's perspective, Guatemala needs help with literacy. It has one a high adult illiteracy rate-24.1\%--according to UNESCO (2015). The illiteracy rate is even higher in rural areas like the one in which they worked. But they failed to take into consideration the circumstances in which the prospective clients found themselves. So this NGO never materialized.

But how would a "TO" organization get off the ground and sustain itself? That would require a continuous flow of outside funding, supplies, and human resources, whether volunteers or employees. Part of the essence of the "TO" organization is the intent to supply unsought goods and services. Classic examples would include religious organizations who send-sometimes successfully and sometimes notmissionaries to developing countries for the purpose of converting the residents of the target countries to their faiths. The recipients usually do not know that they need the conversion. Such organizations may require long-term funding before they can move from "TO" to "FOR" or "WITH." Without such continuous outside funding, TO organizations tend to be ephemeral or, like our example, never to launch. In our sample ten NGOs were classified as "FOR" and three NGO's were classified as "WITH."

\section{AREAS FOR FUTURE RESEARCH}

Our research contribution was the development of the To-For-With Framework and the classification of our sample of 13 NGOs in Guatemala. Specifically there are few "To" NGOs in our sample because they often disappear without connection to the needs of the population. The ones that do exist are often religious and exist solely to convert the population to their beliefs: a need and a purpose that the native population does not necessarily recognize as their own need.

The NGOs classified as "For" in the To-For-With Framework are developing and are greater in number because of their stage of the life cycle. The NGOs classified as "With" in the framework are fewer in 
number but are more willing to talk to "outsiders" as they are less dependent on donors for support.

The implications for the supply chain are many. First, there are lessons to be learned from humanitarian supply chains by commercial, for-profit organizations. While supply chains in developing countries may not be IT-enabled, they often engage in practices that could be used by multinational enterprises who would like to expand operations to these locations. One issue that we uncovered was the difficulty in collecting NGO data due to flawed recordkeeping and the absence of data capture, a factor mentioned by Day et al., (2012).

We also found that researchers living in Guatemala who understood the language and culture could more easily connect with NGO officials in ways that were not available to outside researchers. Many volunteers do not stay in the country for extended periods and do not understand the language and culture and are regarded as tourists or outsiders.

From this research we also recognize that supply chains in developing countries are often fluid, and fluid in ways that might be adapted in commercial circumstances, but there is a dearth of data or literature that can easily introduced into an IT-enabled environment. Many humanitarian supply chains rely on impromptu shipments and impromptu sourcing. Often volunteers and employees of the NGO incorporate key elements of the supply chain like raw materials and supplies into their luggage on their "voluntourism visits." While these practices are not systematic, they are often effective on a small scale.

By the same token, humanitarian supply chains have much to learn from the commercial IT-enabled supply chains in the developed world. Both slow- and fast-developing disasters can benefit from the academic research and the commercial practices - data capture and communication, for example. Much of the academic literature focuses on fast-developing disasters that can happen anywhere (flood, hurricane) but the incipient and constant hunger and poverty of slowdeveloping disasters need different solutions.

Future research must address how to move from one classification to the next in the To-For-With Framework proposed and to highlight cases of NGOs moving upward or downward over time between classifications. Our exploratory research should be extended and the sample size of NGOs increased to further adjust and refine the criteria to better understand circumstances of current NGOs and provide strategic guidance for future NGOs. Future research should replicate these findings for consistency and to further validate the To-For-With Framework and the nine criteria for classification. Additional research should expand the study to larger samples and additional areas of the world.
In-depth case studies of NGOs are needed to better understand their supply chains and challenges. These cases should be crafted for academic literature in business as well as for textbooks to train disaster administrators, NGO officers, and supply chain practitioners. Knowledge of cultural issues and differences in viewpoints of populations in the countries served should be disseminated to volunteer-tourism audiences. Longer focus group interviews to search for and validate key themes in the NGOs best practices are needed to further model and theory development. Longitudinal study on NGOs as they transition from one stage to another in the "TO," "FOR," and "WITH" framework is necessary as well.

\section{REFERENCES}

Abom, B. (2004). Social capital, NGOs, and development: a Guatemalan case study. Development in Practice, 14(3), 342-353.

Ardalan, Kavous (2009), Globalization and culture: four paradigmatic views, International Journal of Social Economics, 36 (5), pp. 513-534.

Astley, W. G. (1985). Administrative science as socially constructed truth. Administrative Science Quarterly, 497-513.

Aurelie, Charles, Lauras, M., and Luk Van Wassenhove. (2010). A model to define and assess the agility of supply chains: building on humanitarian experience, International Journal of Physical Distribution \& Logistics Management, 40 (8/9), pp.722-741

Berry, N. S. (2014). Did we do good? NGOs, conflicts of interest and the evaluation of short-term medical missions in Sololá, Guatemala. Social Science \& Medicine, 120, pp. 344-351.

Blecken, A. (2010). Supply chain process modelling for humanitarian organizations. International Journal of Physical Distribution \& Logistics Management, 40(8), pp.675-692.

Burrell, G., \& Morgan, G. (1979). Sociological paradigms and organisational analysis (Vol. 248). London: Heinemann.

Colyer, W. T. (1922). Americanism: A World Menace. Labour Publishing Company.

Creswell, J. W. (2012). Qualitative Inquiry and Research Design: Choosing Among Five Approaches, Third Edition. Thousand Oaks, CA: Sage Publications, Inc.

Day, J. M., Melnyk, S. A., Larson, P. D., Davis, E. W., \& Whybark, D. C. (2012). Humanitarian and disaster relief supply chains: a matter of life and death. Journal of Supply Chain Management, 48(2), pp. 21-36.

Dworkin, Tex. (2014) Massive Protests Lead Guatemala to Reject 'Monsanto Law' in Court, Case2Make a Difference. Accessed February 16, 2015 at http://www.care2.com/causes/massive-protests-leadguatemala-to-reject-monsanto-law-incourt.html\#ixzz3RkTLgft5

Fenton, K. N., Castillo, S. H., Claro, C. D., \& Novick, W. M. (2011). Teamwork and program organization in 
developing countries. World Journal for Pediatric and Congenital Heart Surgery, 2(2), pp. 219-224.

Gettleman, J. (2015). Meant to Keep Malaria Out, Mosquito Nets are Used to Haul Fish In. New York Times, January 24, A1.

Gibson, B. J., Mentzer, J. T., \& Cook, R. L. (2005). Supply chain management: the pursuit of a consensus definition. Journal of business logistics, 26(2), pp. 1725.

Gustavsson, L. (2003). Humanitarian logistics: context and challenges. Forced Migration Review, 18, pp. 6-8.

Hassini, E., Surti, C., \& Searcy, C. (2012). A literature review and a case study of sustainable supply chains with a focus on metrics. International Journal of Production Economics, 140(1), pp. 69-82.

Helms, M. M., Jones, R. and Takeda, M.B. (2007). Learning from Kobe: Complexity and Urgency in the Holistic Management Model. Japan Studies Review, 11, pp. 23-50. (CTP)

Kiser, A. I., Trevino, N. A., \& McVicker, M. (2009). An economically and environmentally sustainable business model initiative for micro enterprise in Guatemala: Observations from field research. Business Education \& Accreditation, 1(1), pp. 121-130.

Krajewski, L. J., Ritzman, L. P., \& Malhotra, M. K. (2012). Operations management: Processes and supply chains. Pearson Higher Ed.

Lambert, D. M., \& Cooper, M. C. (2000). Issues in supply chain management. Industrial Marketing Management, 29(1), pp. 65-83.

LeMay, S., Holt, L., \& Schmurr, J. (2011, December). Two Stories and Four Concepts: Searching for a Theory of
Supply Chains. In Association of Marketing Theory and Practice 2012.

Mentzer, J. T., DeWitt, W., Keebler, J. S., Min, S., Nix, N. W., Smith, C. D., \& Zacharia, Z. G. (2001). Defining supply chain management. Journal of Business Logistics, 22(2), pp. 1-25.

Merminod, N., Nollet, J., \& Pache, G. (2014). Streamlining humanitarian and peacekeeping supply chains. Society and Business Review, 9(1), pp. 4-22.

Singhal, K., \& Singhal, J. (2012). Imperatives of the science of operations and supply-chain management. Journal of Operations Management, 30(3), pp. 237-244.

Takeda, M.B., and Helms, M. M. (2006). Bureaucracy, Meet Catastrophe: Analysis of Hurricane Katrina Relief Efforts and their Implications for Global Emergency Governance. International Journal of Public Sector Management, 19(4), pp. 397-411.

Takeda, M.B., and Helms, M. M. (2006). Bureaucracy, Meet Catastrophe: Analysis of the Tsunami Disaster Relief Effort and their Implications for Global Emergency Governance. International Journal of Public Sector Management, 19(2), pp. 204-217.

Takeda, M. Helms, M. M. and Jones, R. (2008). Research Note - Learning from Hurricane Katrina: Complexity and Urgency in the Holistic Management Model, Japan Studies Review, 12, pp. 107-124.

Wolcott, H. R. (1994). Transforming Qualitative Data: Description, Analysis, and Interpretation. Thousand Oaks, CA: Sage Publications, Inc.

http://www.uis.unesco.org/literacy/Pages/data-release-map2013.aspx Accessed 23 February 2015.

Dr. Stephen A. LeMay is Associate Professor of Marketing and Logistics at the University of West Florida, and Professor Emeritus of Marketing and Logistics at Mississippi State University. He holds a doctorate in transportation and logistics from the University of Tennessee, Knoxville, an MBA in operations management from the University of Tennessee at Knoxville, and a bachelor's degree in journalism from Northwestern University. He was lead researcher and author on the 1999 book, The Growth and Development of Logistics Personnel, the product of a research project sponsored by the Council of Supply Chain Management Professionals. He also coauthored a textbook, Logistics, that has been translated into Mandarin and Croatian. He led a team that created an assembled the Logistics Toolbox, a collection of educational materials designed for people who are new to logistics work. This work was first published by the CSCMP in 2002, then revised in 2005. Dr. LeMay's published work includes more than 75 academic journal articles and proceedings. His research interests include logistics system design, security, logistics information systems, and logistics human resources issues. He has taught a wide range of business courses including logistics, marketing, operations management, and management classes.

Michael J. P. Dwyer is an independent researcher studying humanitarian/disaster relief supply chains and the relationships formed among aid organizations in Antigua, Guatemala. Mr. Dwyer earned his M.B.A. from University of West Florida in 2013. He also holds a B.A. from James Madison University in philosophy. His published works include conference proceedings, "The Antecedents and Consequents of Internal Customer Orientation in the Logistics Workforce" and "The Effects of a Disaster's Onset on Humanitarian Aid Supply Chains," and the journal article "MetaSpace Designs LLC: Can a Lapel-ephant Stay Relevant?" He served as a crew chief in the United States Air Force and as a business development analyst for Catalyst CRE in Pensacola, Florida. His research has appeared in major international conferences and case-related journals. His research interests include the effects of foreign aid workers on domestic populations, long-term community development strategic planning, and networking of non-government organizations deployed in distressed areas. 
Dr. Marilyn M. Helms holds the Sesquicentennial Chair and is a Professor of Management at Dalton State College in Dalton, GA. Dr. Helms holds a Doctorate of Business Administration Degree (as well as an M.B.A. and B.B.A.) from the University of Memphis (TN). Dr. Helms also teaches graduate supply chain/operations management in the Kennesaw Coles College of Business MBA Program on the DSC campus. She is a Certified Fellow in Production and Inventory Management (CFPIM), a Certified Integrated Resources Manager (CIRM), and a Certified Supply Chain Professional (CSCP) of the American Production and Inventory Control Society (APICS). Dr. Helms is also a faculty member of the APICS Basics of Supply Chain Certification Exam committee and works with practitioners and consultants to author and oversee the exam content, study materials, and process. Dr. Helms is a Certified Quality Manager/ Organizational Excellence (CQM/OE) as awarded by the American Society for Quality (ASQ). Her research interests include disaster management, supply chains, strategic management, and entrepreneurship. 